\title{
Insulin-like growth factor-I stimulates gonadotrophin production from eel pituitary cells: a possible metabolic signal for induction of puberty
}

\author{
Y-S Huang, K Rousseau, N Le Belle, B Vidal, E Burzawa-Gérard, \\ J Marchelidon and S Dufour
}

Laboratoire de Physiologie Générale et Comparée, Muséum National d'Histoire Naturelle, URA 90 CNRS, 7 rue Cuvier, 75231 Paris Cedex 05, France (Requests for offprints should be addressed to S Dufour)

\begin{abstract}
Insulin-like growth factor (IGF)-I has been suggested as a potential signal linking growth and puberty in mammals. Using the juvenile European eel as a model, we employed a long-term, serum-free primary culture of pituitary cells to study the direct effect of IGF-I on gonadotrophin $(\mathrm{GtH}-\mathrm{II}=\mathrm{LH})$ production. IGF-I increased both cell content and release of GtH-II in a time- and dose-dependent manner. IGF-I and IGF-II had similar potencies but insulin was 100-fold less effective, suggesting the implication of an IGF type 1 receptor. Other growth and metabolic factors, such as basic fibroblast growth factor and thyroid hormones, had no effect on GtH-II production. IGF-I did not significantly increase the number of GtH-II immunoreactive cells, indicating that its stimulatory effect
\end{abstract}

on GtH-II production does not result from gonadotroph proliferation. Comparison of IGF-I and somatostatin (SRIH-14) effects showed that both factors inhibited growth hormone $(\mathrm{GH})$ release but only IGF-I stimulated GtH-II production by eel pituitary cells. This indicates that the effect of IGF-I on gonadotrophs is not mediated by the reduction of GH released by somatotrophs into the culture medium. This study demonstrates a specific stimulatory effect of IGF-I on eel GtH-II production, played out directly at the pituitary level. These data obtained in a primitive teleost suggest that the role of IGF-I as a link between body growth and puberty may have been established early in the evolution of vertebrates.

Journal of Endocrinology (1998) 159, 43-52

\section{Introduction}

In mammals, data suggest that the initiation and progression of the pubertal process may be influenced by metabolic factors of peripheral origin (see reviews by Ojeda \& Urbanski 1988, Plant 1988). Experimental observations first carried out in the rat showed a minimal body size or fat content was involved in the onset of puberty (Kennedy \& Mitra 1963, Frisch \& McArthur 1974, Frisch et al. 1977). Clinical observations fit this hypothesis, as children with delayed body growth usually also present with delayed sexual development (e.g. Stanhope et al. 1987), and growth hormone $(\mathrm{GH})$ treatment in prepubertal children presents a risk of inducing precocious puberty (Colle \& Broussin 1993). Moreover, recent data from transgenic rats expressing the $\mathrm{GH}$ gene show precocious puberty in these animals (Ikeda et al. 1994).

In fish, as in mammals, a positive relationship between body growth and age at first reproduction ('puberty') has also been observed. For instance, results obtained from various strains of salmonids indicate that early puberty depends on a high growth rate (review: Le Bail 1988). In male Masu salmon (Oncorhynchus masu), the precocious puberty that occurs in some under-yearling fish can be related to a higher body growth rate (Amano et al. 1997).

Recent studies in mammals suggest that insulin-like growth factor (IGF)-I, a growth factor mainly produced by the liver under the stimulatory control of GH (see reviews by Froesch et al. 1985, Cohick \& Clemmons 1993) could be a good candidate for a link between somatic development and pubertal activation of reproductive function. Indeed, circulating levels of IGF-I increase strikingly during puberty in rodents (Handelsman et al. 1987, Takahashi et al. 1997), ruminants (Roberts et al. 1990) and primates (Copeland et al. 1982, 1985), including humans (Luna et al. 1983, Anders et al. 1994).

However, few data are available concerning the possible mechanisms of IGF-I action in activating puberty. Some studies suggest that besides its autocrine/paracrine stimulatory effects on gonadal function (review: Giudice 1992), IGF-I could play a key role in the onset of puberty by acting centrally on the hypothalamo-pituitarygonadotrophic axis. Hiney et al. (1996) reported that, at the time of puberty in the rat, the increase in circulating IGF-I levels is accompanied by an increased synthesis of IGF-I receptors in the median eminence. The same 
authors also showed that intraventricular administration of IGF-I increased plasma luteinizing hormone (LH) levels and advanced the onset of puberty. In vitro data also showed that, in the rat, IGF-I could stimulate gonadotrophin-releasing hormone $(\mathrm{GnRH})$ release from the median eminence (Hiney et al. 1991), and release of gonadotrophins (LH and follicle stimulating hormone, FSH) from pituitary cells (Kanematsu et al. 1991, Soldani et al. 1994, 1995).

A strong molecular and functional conservation of IGF-I is observed among all classes of vertebrates (review: Upton et al. 1997). In teleosts, as in mammals, IGF-I is mainly produced by the liver under the control of $\mathrm{GH}$ (Funkenstein et al. 1990, Shamblott et al. 1995, Duguay et al. 1996) and plays, with GH itself, an important role in regulating body growth (see reviews by Chan \& Steiner 1994, Plisetskaya et al. 1994). Some data also suggest that IGF-I may participate in the direct regulation of the gonads in teleosts (Duguay et al. 1992, Duan et al. 1993, Gutiérrez et al. 1993, Kagawa et al. 1995, and review by Le Gac et al. 1993), as it does in mammals (Hansson et al. 1989, Monniaux \& Pisselet 1992, and review by Giudice 1992). As to its central actions, an inhibitory effect on GH secretion was demonstrated in the rainbow trout (Oncorhynchus mykiss) (Pérez-Sànchez et al. 1992, Blaise et al. 1995) and in the European eel (Anguilla anguilla) (Rousseau et al. 1998), indicating a classical negative feedback on the somatotrophic axis, as in mammals (Berelowitz et al. 1981, Yamashita \& Melmed 1986). However, no data are yet available on the possible actions of IGF-I on the gonadotrophic axis in non-mammalian vertebrates.

In the present study, we looked for the possible direct pituitary effect of IGF-I on the production of type II gonadotrophin (GtH-II, teleost gonadotrophin homologous to tetrapod LH: Quérat 1994, Swanson \& Dittman 1997) in the European eel. This animal model is particularly appropriate for studying mechanisms of experimental stimulation of puberty. First, it has a striking life cycle with a long period of juvenile growth (yellow stage). Secondly, sexual development is still blocked at a prepubertal stage even when the eels begin their reproductive migration (silver stage) (reviews: Dufour et al. 1983b, Dufour 1994). Thirdly, the phylogenetical position of the eel, a member of the group of Elopomorphs considered to be close to the origin of teleost evolution, may provide information on ancestral regulations in vertebrates (Lauder \& Liem 1983, Roberts et al. 1989).

In order to study the direct pituitary effect of IGF-I on eel GtH-II production, we used a long-term, serum-free system of primary cultures of eel pituitary cells that we have recently developed (Huang et al. 1997). Comparisons of the effects of other growth and hormonal factors on $\mathrm{GtH}-\mathrm{II}$, as well as on GH in the same culture system, were also performed to test the specificity of IGF-I action. Preliminary results have been presented at the Third
International Symposium on Research for Aquaculture (Huang et al. 1998).

\section{Materials and Methods}

\section{Animals}

Several batches of juvenile (yellow stage) female eels (Anguilla anguilla L.), caught during spring and summer in north or west France, were transferred to the laboratory and kept in running aerated freshwater for short periods (from one to a few weeks) until used. Their body weights were between 100 and $200 \mathrm{~g}$, and their gonadosomatic indexes were below $0 \cdot 7 \%$.

\section{Hormones}

Human recombinant insulin-like growth factor-I (IGF-I, somatomedin C), human recombinant insulin-like growth factor-II (IGF-II) and bovine recombinant basic fibroblast growth factor (bFGF) were obtained from Boehringer Mannheim (Meylan, France). Somatostatin (SRIH-14), human recombinant insulin and thyroid hormones (triiodothyronine $\left(\mathrm{T}_{3}\right)$ and thyroxine $\left(\mathrm{T}_{4}\right)$ ) were obtained from Sigma (St Quentin-Fallavier, France). Stock solutions $\left(10^{-3}\right.$ or $\left.10^{-4} \mathrm{M}\right)$ were prepared in pure sterile water (Sigma) for IGF-I, IGF-II, bFGF and SRIH-14, in $0 \cdot 1 \mathrm{M}$ acetic acid for insulin and in $0 \cdot 1 \mathrm{M} \mathrm{NaOH}$ for $\mathrm{T}_{3}$ and $\mathrm{T}_{4}$. Stock solutions were aliquoted and kept at $-20{ }^{\circ} \mathrm{C}$; further dilutions were prepared in culture medium just before addition to the wells.

\section{Primary culture of eel pituitary cells and in vitro treatments}

Dispersion of eel pituitary cells was performed using an enzymatic and mechanical procedure as previously described by Montero et al. (1996). About 100 eels were used for each dispersion. Cells were cultured on poly-L-lysine precoated plates (96 wells/plate; Costar, Cambridge, MA, USA) at a density of 62500 cells/well in serum-free culture medium (M199 with Earle's salt, sodium bicarbonate, $100 \mathrm{U} / \mathrm{ml}$ penicillin, $100 \mu \mathrm{g} / \mathrm{ml}$ streptomycin, $250 \mathrm{ng} / \mathrm{ml}$ fungizone; Gibco, CergyPontoise, France), in a $\mathrm{CO}_{2}$ incubator (NAPCO, ATGC, Noisy-Le Grand, France) at $18{ }^{\circ} \mathrm{C}$, as described by Huang et al. (1997). Treatments were started after $24 \mathrm{~h}$ of preculture. Media and treatments were renewed every 3 days for up to 15 days. Cultures were stopped before addition of hormones (day 0 ) or at various times of culture up to 15 days. GtH-II and GH contents in cells were assayed after submitting cells to osmotic shock and two repeated cycles of freezing and thawing (Huang et al. 1997, Rousseau et al. 1998). Replicates of 6 wells were used for each treatment. Collected media and cell extracts were kept frozen $\left(-20{ }^{\circ} \mathrm{C}\right)$ until radioimmunoassay (RIA). 


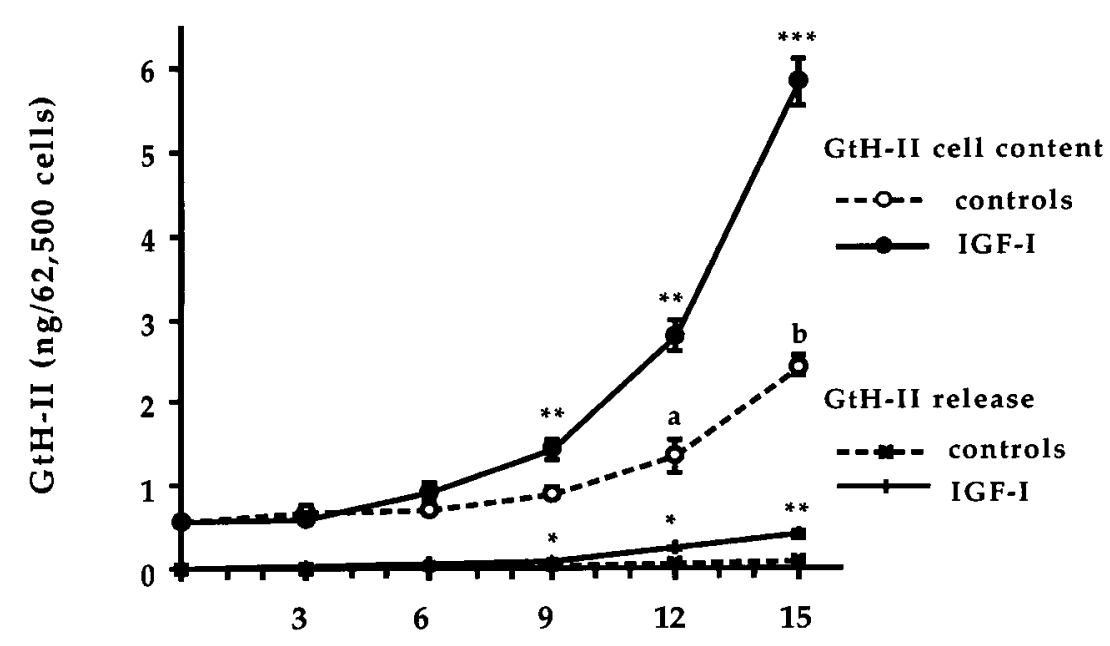

\section{Duration of in vitro cell treatment (days)}

Figure 1 Time course of the effect of IGF-I $\left(10^{-8} \mathrm{M}\right)$ on eel GtH-II cell content and release. Cells were cultured in serum-free medium (see Materials and Methods). Cultures were stopped on day 0 (before IGF-I addition) and at various times up to 15 days to measure GtH-II cell content. GtH-II release is calculated as cumulated release up to day 15 , the medium and treatment being renewed every 3 days. Results are means \pm S.E.M. $(n=6$ wells/group; 62500 cells/wells). ${ }^{*} P<0 \cdot 05,{ }^{* *} P<0 \cdot 01,{ }^{* * *} P<0 \cdot 001$ vs controls at the same time point; ${ }^{\mathrm{a}} P<0 \cdot 05,{ }^{\mathrm{b}} P<0 \cdot 01$ vs controls at day 0 (variance analysis).

\section{Radioimmunoassays}

GtH-II and GH from intracellular content and culture media were assayed in duplicate using respectively an RIA for carp GtH-II $\beta$ subunit validated for eel GtH-II (Dufour et al. 1983a) and an homologous RIA for eel GH (Marchelidon et al. 1996). Total GtH-II or GH released into the culture medium was calculated by cumulating GtH-II or GH released every 3 days. GtH-II stimulation and $\mathrm{GH}$ inhibition in treated wells were calculated as a percentage of mean content or release by control wells in the same experiment.

\section{Immunocytochemistry}

Immunocytochemical characterization of GtH-II cells was performed as previously described (Montero et al. 1996). Dispersed pituitary cells were cultured on poly-L-lysine precoated coverslips (Nunc, Naperville, IL, USA) placed in 24-well plates (Costar) at a density of 150000 cells/ well. Cells were cultured for 12 days in the presence or absence of $10^{-7} \mathrm{M}$ IGF-I. Media and treatment were renewed every 3 days. After 12 days, cells were fixed in $2 \%$ paraformaldehyde in $0.05 \mathrm{M}$ sodium phosphate buffer and $0 \cdot 15 \mathrm{M} \mathrm{NaCl}$ for $2 \mathrm{~h}$ at room temperature. Nonspecific sites were saturated by incubation with $10 \%$ normal goat serum (Biosys, Compiègne, France) for $1 \mathrm{~h}$ at room temperature. Primary antibody (rabbit antiserum to carp GtH-II, the same as for the RIA; dilution 1/5000) was incubated overnight at $4{ }^{\circ} \mathrm{C}$. Secondary antibody (goat antiserum to rabbit immunoglobulins coupled to peroxidase; Biosys; dilution 1/100) was incubated for $1 \mathrm{~h}$ at $25{ }^{\circ} \mathrm{C}$. Peroxidase activity was revealed with a solution of 0.003\% 4-chloro-1-naphtol (Sigma) and 0.03\% hydrogen peroxide in $0.05 \mathrm{M}$ Tris-buffer. Three independent experiments were performed. Counting of total cell number per well area and of GtH-II immunoreactive cells (ir-GtH-II cells) was performed using an image analyser LEITZ DMR (Germany).

\section{Statistical analysis}

Each experiment was repeated in 3 independent studies (performed on different cell preparations). Results of representative experiments are shown. For each experiment, replicates of 6 wells were used for each treatment and values are given as means \pm s.E.M. Homogeneity of variance was assessed by Bartlett's test, and data from different groups were compared by one-way analysis of variance followed by Student-Newman-Keuls multiple comparisons test.

\section{Results}

Long-term kinetics of the effects of IGF-I on GtH-II cell content and release (Fig. 1)

In control wells, a time-dependent increase in GtH-II cell content was observed. As compared with the initial 


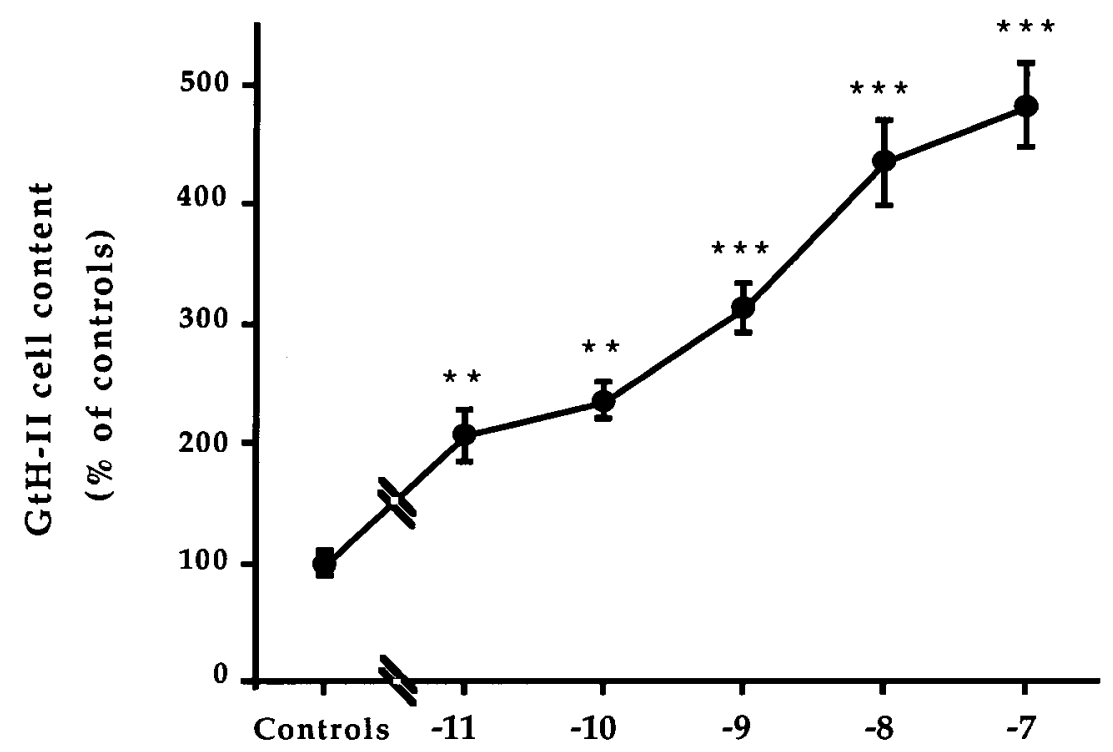

IGF-I concentration $(\log M)$

Figure 2 Dose-dependent effect of IGF-I on GtH-II cell content. Cultures were stopped on day 12 after addition (or not, controls) of various doses of IGF-I, to measure GtH-II cell content by RIA. Media and treatment were renewed every 3 days. Results are expressed as percentage of mean value of $\mathrm{GtH}$-II cell content in controls. Values are given as means \pm S.E.M. ( $n=6$ wells/group; 62500 cells/wells). ${ }^{*} P<0 \cdot 01,{ }^{* * *} P<0 \cdot 001$ vs controls (variance analysis).

content (day 0: $0 \cdot 57 \pm 0 \cdot 06 \mathrm{ng} / 62500$ cells), GtH-II cell content was significantly increased at day $12(2 \cdot 37$ times compared with day $0, P<0 \cdot 05)$ and at day $15(4 \cdot 3$ times compared with day $0, \quad P<0 \cdot 01)$. Addition of IGF-I $\left(10^{-8} \mathrm{M}\right)$ strongly increased GtH-II cell content, which reached a value at day $15(5 \cdot 84 \pm 0 \cdot 28 \mathrm{ng} / 62500$ cells $)$ 10 -fold higher than the initial GtH-II cell content $(P<0 \cdot 001)$. As compared with control cells at the same culture time, the stimulatory effect of $10^{-8} \mathrm{M}$ IGF-I on GtH-II cell content was time-dependent $(135 \% P>0 \cdot 05$; 157\% $P<0 \cdot 01 ; 207 \% P<0 \cdot 01 ; 240 \%, P<0 \cdot 001$, for $6,9,12$ and 15 days of cell treatment respectively).

GtH-II release was low in control and IGF-I-treated wells, representing only a small percentage of the final cell content over 15 days of culture. A significant increase in cumulated GtH-II released was observed after 9 days of IGF-I treatment compared with control wells $(P<0 \cdot 05)$. Cumulated GtH-II released over 15 days of culture reached $0.40 \pm 0.02 \mathrm{ng} / 62500$ cells in IGF-I-treated wells versus $0.08 \pm 0.02 \mathrm{ng} / 62500$ cells in control wells $(P<0 \cdot 01)$.

\section{Dose-dependent effect of IGF-I on GtH-II cell content (Fig. 2)}

The effects of various doses of IGF-I were tested over 12 days of treatment. IGF-I showed a dose-dependent stimulatory effect on GtH-II cell content, with a significant effect at $10^{-11} \mathrm{M}(P<0 \cdot 01)$. The highest concentration tested $\left(10^{-7} \mathrm{M}\right)$ gave a maximal stimulation of $480 \%$ $(P<0 \cdot 001)$. The $\mathrm{EC}_{50}$ was $10^{-10} \mathrm{M}$.

Comparative effects of IGF-I, IGF-II, insulin and bFGF on GtH-II cell content (Fig. 3)

The effects of various factors belonging to the insulin-like superfamily (IGF-I, IGF-II and insulin) and of another type of growth factor family (bFGF) were compared over 12 days of treatment. GtH-II cell content was increased in a dose-dependent manner by IGF-I and IGF-II, with a similar maximal stimulation (423 and 445\% respectively) at the highest dose tested $\left(10^{-7} \mathrm{M}\right)$. Insulin was less potent, with a significant effect at $10^{-7} \mathrm{M}(P<0 \cdot 001)$, equivalent to that produced by $10^{-9} \mathrm{M}$ IGF-I or IGF-II. In contrast, no significant effect was observed with bFGF at any dose tested.

\section{Comparative effects of IGF-I and thyroid hormones on GtH-II cell content (Fig. 4)}

The effects of thyroid hormones $\left(\mathrm{T}_{3}\right.$ and $\left.\mathrm{T}_{4}\right)$ on GtH-II cell content were tested at various doses, and compared with the effect of IGF-I over 12 days of treatment. Neither $\mathrm{T}_{3}$ nor $\mathrm{T}_{4}$ had any significant effects on GtH-II cell 


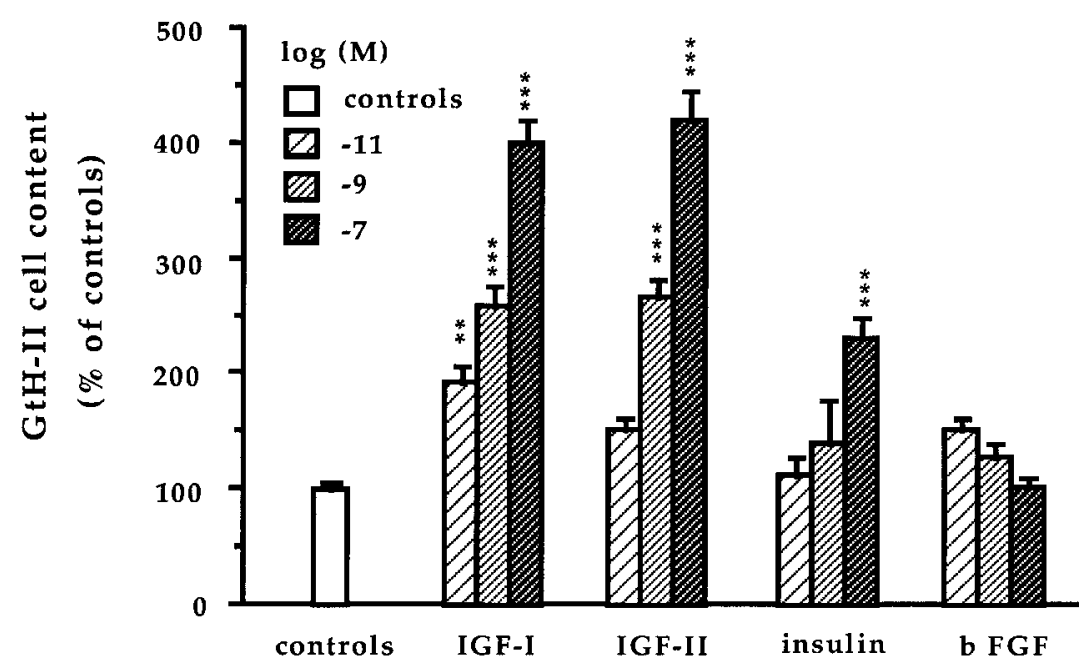

Figure 3 Effects of various doses of IGF-I, IGF-II, insulin and bFGF on GtH-II cell content. Cultures were stopped on day 12 after addition (or not, controls) of various doses of IGF-I, IGF-II, insulin or bFGF, to measure GtH-II cell content by RIA. Media and treatments were renewed every 3 days. Results are expressed as percentage of mean value of $\mathrm{GtH}-\mathrm{Il}$ cell content in controls. Values are given as means \pm S.E.M. ( $n=6$ wells/group; 62500 cells/wells). ${ }^{*} P<0 \cdot 01,{ }^{* *} P<0 \cdot 001$ vs controls (variance analysis).

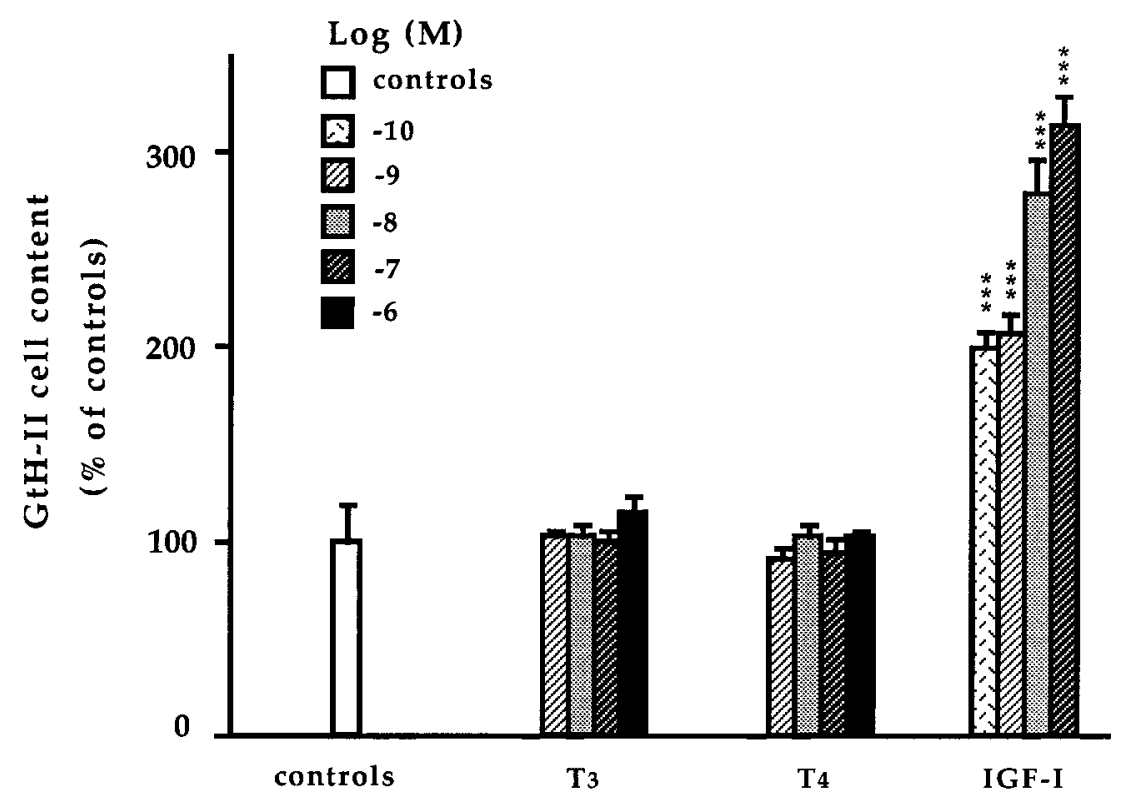

Figure 4 Effects of various doses of IGF-I, $\mathrm{T}_{3}$ and $\mathrm{T}_{4}$ on $\mathrm{GtH}-\mathrm{II}$ cell content. Cultures were stopped on day 12 after addition (or not, controls) of various doses of IGF-I, $\mathrm{T}_{3}$ or $\mathrm{T}_{4}$, to measure GtH-II cell content by RIA. Media and treatments were renewed every 3 days. Results are expressed as percentage of mean value of GtH-II cell content in controls. Values are given as means \pm S.E.M. ( $n=6$ wells/group; 62500 cells/wells). ${ }^{* * *} P<0 \cdot 001$ vs controls (variance analysis).

content at any dose tested (from $10^{-9}$ to $10^{-6} \mathrm{M}$ ). In contrast, IGF-I significantly increased GtH-II cell content in a dose-dependent manner, in the same experimental conditions.
Effect of IGF-I on the number of GtH-II immunoreactive cells

The effect of $10^{-7} \mathrm{M}$ IGF-I on GtH-II cell number was tested over 12 days of culture. Gonadotrophs were 


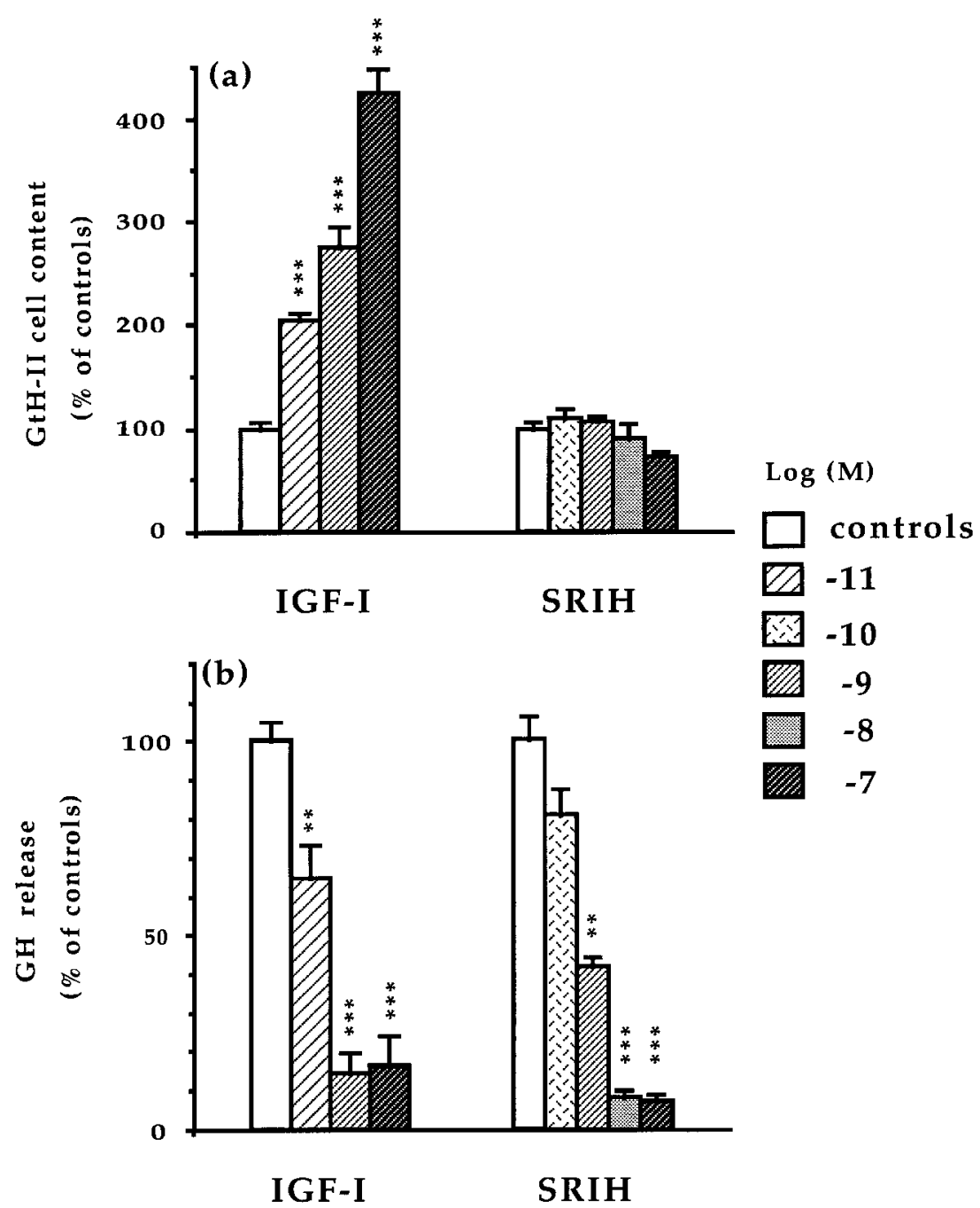

Figure 5 Comparative effects of IGF-I and SRIH-14 on (a) GtH-II cell content and (b) GH release. Cultures were stopped on day 12 after addition (or not, controls) of various doses of IGF-I or SRIH-14, to measure GtH-II cell content by RIA. Media and treatments were renewed every 3 days. Results are expressed as percentage of mean value of GtH-II cell content in controls. Total $\mathrm{GH}$ released over 12 days of culture was expressed as a percentage of the mean value of total $\mathrm{GH}$ released in control wells. Values are given as means \pm S.E.M. ( $n=6$ wells/group; 62500 cells/wells). ${ }^{* *} P<0 \cdot 01,{ }^{* * *} P<0 \cdot 001$ vs controls (variance analysis).

identified by immunocytochemistry. Counting of total pituitary cells per well area showed no differences between control and IGF-I-treated wells. Immunoreactive GtH-II cells were found to represent $4 \cdot 42 \pm 0 \cdot 61 \%$ of total cells in control wells and $5 \cdot 33 \pm 0 \cdot 58 \%$ in IGF-I-treated wells, indicating no significant effect of IGF-I on GtH-II cell number $(P>0 \cdot 05$, Student's $t$-test; 3 independent experiments, $\geq 800$ cells counted/treatment/experiment). In the same experiments, we assessed that IGF-I stimulated GtH-II production.
Comparative effects of IGF-I and SRIH-14 on GtH-II cell content and GH release (Fig. 5)

In order to address the question whether the stimulatory effect of IGF-I on GtH-II could be mediated by its inhibitory effect on GH release, we compared the effects of IGF-I and SRIH-14, both factors previously shown to inhibit GH release (Rousseau et al. 1998). Various doses of SRIH-14 and IGF-I were tested over 12 days of culture. Both factors dose-dependently inhibited GH release, with 
maximal inhibitory effects of $85 \%$ at $10^{-9} \mathrm{M}$ IGF-I and $90 \%$ at $10^{-8} \mathrm{M}$ SRIH (Fig. 5b). In contrast, only IGF-I showed a dose-dependent stimulatory effect on GtH-II cell content, SRIH having no significant effect on GtH-II cell content at any dose tested (from $10^{-10}$ to $10^{-7} \mathrm{M}$ ) (Fig. 5a).

\section{Discussion}

In this series of experiments we used long-term, serumfree primary cultures of eel pituitary cells to investigate the effect of IGF-I on GtH-II production. This model has already proved useful for studying pituitary function in defined conditions, in particular for analysing the regulation of GtH-II (Huang et al. 1997) and GH production (Rousseau et al. 1998).

A significant increase in GtH-II cell content, as well as a slight but significant release of GtH-II, were observed in control cells over 2 weeks of culture. This confirms previous observations by Huang et al. (1997) that eel gonadotrophs can sustain the production of GtH-II over the long-term in serum-free culture conditions. A similar result was recently obtained when investigating $\mathrm{GH}$ production by eel somatotrophs in culture (Rousseau et al. 1998). The serum-free conditions are particulary suitable for the study of the specific effects of growth factors on hormone production by pituitary cells, because no interference from other exogenous hormonal or growth factors present in sera can occur.

The present results show that IGF-I increased GtH-II cell content in a time- and dose-dependent manner. At 12 days of culture, its effect was significant at a dose of $10^{-11} \mathrm{M}$ and reached a maximum (300 to $500 \%$ of stimulation) at $10^{-7} \mathrm{M}$. IGF-I also significantly stimulated GtH-II release. The increases in both cell content and release indicate a stimulation of $\mathrm{GtH}-\mathrm{II}$ production. In the same culture conditions, we have previously demonstrated a stimulatory effect of androgens, but not of oestradiol, on GtH-II production (Huang et al. 1997). Further studies will be aimed at investigating the possible interactions between IGF-I and sex steroids on GtH-II production.

This study provides the first demonstration of a stimulatory effect of IGF-I on gonadotroph activity in teleosts. Indeed, Blaise et al. (1997) found a permissive effect of 48-h preincubation with IGF-I on GnRH-stimulated GH release in vitro by somatotrophs in the rainbow trout (Oncorhynchus mykiss), but they did not observe any significant effect of IGF-I on basal or on GnRHstimulated GtH-II release by gonadotrophs. In mammals some data demonstrate a positive effect of IGF-I on basal or GnRH-stimulated gonadotrophin release in vitro. In the rat, IGF-I was shown to increase basal release of FSH and LH by pituitary cells from mature females and to enhance basal as well as GnRH-stimulated LH release by pituitary cells from immature male rats (Soldani et al. 1994). In addition, IGF-I was shown to stimulate the secretion of FSH, but not LH, by dispersed human anterior pituitary adenomas (Atkin et al. 1993). In pituitary cell cultures from mature female rats, measurement of cell content indicated that neither the production of LH nor FSH was significantly stimulated by IGF-I after $72 \mathrm{~h}$ of treatment (Kanematsu et al. 1991). The model of juvenile eel gonadotrophs is particularly useful for displaying the stimulatory action of regulatory factors on GtH-II production (Huang et al. 1997). First, gonadotrophs from juvenile eels exhibit low initial GtH-II cell content and release (Montero et al. 1996). Secondly, gonadotrophs can sustain their activity for up to 3 weeks of culture in serum-free conditions (Huang et al. 1997), allowing long-term studies of the action of regulatory factors. It is the combination of these characteristics that has allowed this first experimental demonstration of a striking positive effect of IGF-I on GtH production.

In this study we used mammalian (human recombinant) IGF-I, since a high degree of molecular conservation has been shown for IGF-I from teleosts to mammals (Cao et al. 1989, and review by Upton et al. 1997). Moreover, mammalian IGF-I has been shown to be biologically active in the eel in two experimental situations. On the one hand, bovine recombinant IGF-I stimulated in vivo sulphate uptake by branchial cartilage in the Japanese eel (Anguilla japonica) (Duan \& Hirano 1990, 1992), and on the other hand, we recently showed that human recombinant IGF-I strongly inhibited GH release from European eel pituitary cells in vitro (Rousseau et al. 1998).

In order to test the specificity of IGF-I action, we compared the effects of three members of the insulin-like superfamily, human recombinant IGF-I, IGF-II and insulin. IGF-I and IGF-II had similar capacities (same dosedependences and maximal effects) in increasing eel GtH-II cell content. In contrast, insulin was at least 100 times less potent. This agrees with the demonstration, in the trout pituitary, of binding sites having the same high affinity for IGF-I and IGF-II and a lower affinity for insulin (Blaise et al. 1995). According to the classification in mammals (see review by Jones \& Clemmons 1995), these binding properties are characteristic of the type 1 IGF receptor. The recent cloning of IGF type 1 receptor in two teleosts, trout (Oncorhynchus mykiss) and turbot (Scophthalmus maximus), showed that, like IGFs, IGF type 1 receptor polypeptide sequences are highly conserved (>90\% identity) among vertebrates (Elies et al. 1996). The specificity of IGF action was further demonstrated by the lack of effect of bFGF, a growth factor unrelated to the insulinlike superfamily. We also compared the effect of thyroid hormones $\left(\mathrm{T}_{4}\right.$ and $\left.\mathrm{T}_{3}\right)$ known to play a major role in the control of development, growth and metabolism in vertebrates (see review by McNabb 1994). Neither $T_{3}$ nor $T_{4}$ had any significant effect on GtH-II cell content at any dose tested (from $10^{-9}$ to $10^{-6} \mathrm{M}$ ). This further emphasizes the specificity of the stimulatory effect of IGF-I on gonadotrophs. 
As IGF-I is a known mitogenic factor involved in cell growth (review: Cohick \& Clemmons 1993), it was conceivable that the stimulatory effect on GtH-II production could result from proliferation of gonadotrophs. However, counting immunoreactive gonadotrophs after 12 days of culture did not show any significant difference between control cells and cells treated with a maximal dose of IGF-I $\left(10^{-7} \mathrm{M}\right)$. In mammals, similar data have been obtained indicating that IGF-I does not stimulate proliferation of gonadotrophs in vitro (rat: Tilemans et al. 1991, Soldani et al. 1994; mice: Takahashi et al. 1997). This suggests that the stimulatory effect of IGF-I on eel GtH-II production results from increased GtH-II production per cell rather than from gonadotroph proliferation. Our experimental observations support this finding as the immunoreactive intensity of gonadotrophs appeared stronger in IGF-treated cells than in control cells (data not shown).

Since IGF-I also exerts an inhibitory effect on GH release in teleosts as it does in mammals, and as we used a mixed pituitary cell population, we investigated whether the stimulatory effect of IGF-I on gonadotrophs could be mediated by the reduction of $\mathrm{GH}$ released into the culture medium. We compared the effects of IGF-I and SRIH14 , both previously having been shown strongly to inhibit GH release by eel pituitary cells in vitro (Rousseau et al. 1998). In the present experiments, while both factors dose-dependently inhibited GH release, only IGF-I had a stimulatory effect on GtH-II cell content, SRIH-14 showing no significant effect at any dose tested (from $10^{-10}$ to $10^{-7} \mathrm{M}$ ). This demonstrates that the stimulatory effect of IGF-I on gonadotrophs is not mediated by GH. However, the possibility that some paracrine factors, possibly produced by somatotrophs or other pituitary cell types under the action of IGF-I, could be involved in the activation of gonadotrophs cannot be excluded. Indeed numerous paracrine factors have been shown to be potentially involved in intercellular communication within the anterior pituitary in mammals (review: Schwartz \& Cherny 1992). In mice, IGF type 1 receptor mRNA has been detected only on pituitary somatotrophs and some corticotrophs (Takahashi et al. 1997). Further studies on IGF-I receptor localisation on pituitary cells in teleosts and mammals are required to determine if gonadotrophs are a direct target of IGF-I.

In the eel, IGF-I and IGF-II exhibit similar in vitro abilities to stimulate GtH-II production. In mammals, in vitro studies also revealed similar potencies of IGF-I and IGF-II on LH release (Soldani et al. 1994). These data suggest that both IGFs could exert potential physiological roles in the pubertal stimulation of gonadotrophins. In mammals, an endocrine role at puberty has been attributed to peripheral IGF-I (review: Thissen et al. 1994), since its plasma levels strongly increase at puberty (see Introduction). In fish, the production of IGF-I by the liver is under GH control, as it is in mammals. Thus IGF-I could play the same endocrine role in the two groups. However, no data are yet available concerning the variations in IGF-I

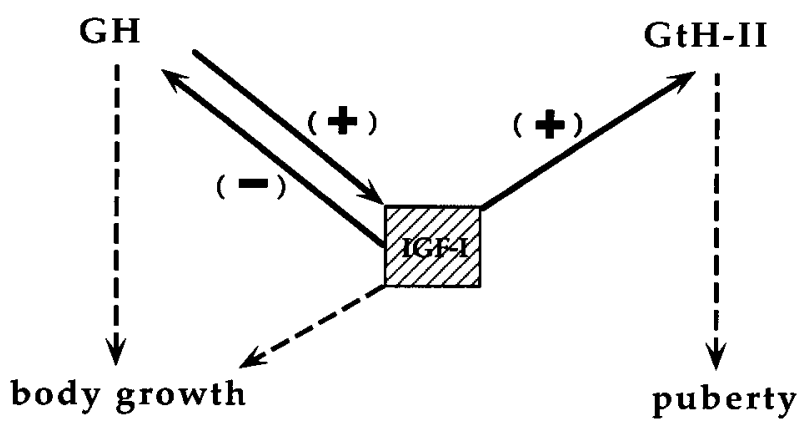

Figure 6 Role of IGF-I as a link between somatic development and induction of puberty. IGF-I, a growth factor mainly produced by the liver under the control of $\mathrm{GH}$, exerts a negative feedback on $\mathrm{GH}$ and a stimulatory effect on $\mathrm{GtH}-\mathrm{II}$, at the pituitary cell level in the eel. GH itself has no direct action on GtH-II. Solid arrows represent the direct controls between IGF-I and pituitary hormones; broken arrows represent the physiological effects. The stimulatory effect of IGF-I on GtH-II (LH-like) makes it a good candidate for a role in the metabolic signal for the induction of the first sexual maturation (puberty).

plasma levels at puberty in fish. Much less is known about IGF-II function and regulation in both mammals and fish. In the juvenile rainbow trout (Oncorhynchus mykiss), Shamblott et al. (1995) showed a GH-dependent stimulation of both IGF-I and IGF-II messenger RNA levels in the liver, and suggested possible endocrine roles for both IGFs. However, in the gilthead seabream (Sparus aurata), Duguay et al. (1996) found a stimulatory effect of GH on hepatic IGF-I, but not IGF-II, mRNA levels.

Some data in mammals indicate that IGF-I acts on the gonadotrophic axis at the hypothalamic level by stimulating GnRH release (Hiney et al. 1991, 1996), and at the pituitary level by stimulating $\mathrm{LH}$ and FSH release (Kanematsu et al. 1991, Soldani et al. 1994, 1995). Our long-term culture system of pituitary cells from a juvenile fish allowed us to demonstrate that IGF-I not only stimulates GtH-II release but is also able strongly to increase GtH-II cell content. This direct stimulatory effect of IGF-I on GtH-II (LH-like) production may play a critical role in the pubertal stimulation of the gonadotrophic axis (Fig. 6). Future studies will aim to investigate whether the in vitro stimulatory effect of IGF-I on GtH-II production can also be demonstrated in vivo. The present data, obtained in a primitive teleost, suggest that the physiological role of IGF-I in the link between body growth and puberty may have been established early in the evolution of vertebrates.

\section{Acknowledgements}

Y S Huang is a recipient of a $\mathrm{PhD}$ fellowship from the MAE (Ministère des Affaires Etrangères) and K Rousseau of a $\mathrm{PhD}$ fellowship from the MRE (Ministère de la Recherche et de l'Education). We thank Professor B 
Demeneix (MNHN, Paris) for critical reading of the manuscript and correcting the English. This work was supported by research grants from CNRS (PICS Taiwan no 487), Conseil Supérieur de la Pêche (no 97/442) and IFREMER (no 962527160 DRV) to S Dufour.

\section{References}

Amano M, Kitamura S, Ikuta K, Suzuki Y \& Aida K 1997 Activation of salmon GnRH mRNA expression prior to differentiation of precocious male in Masu salmon. General and Comparative Endocrinology 105 365-371.

Anders J, Bang P, Hertel NT, Main K, Dalgaard K, Muller J, Hall K \& Skakkebaek NE 1994 Serum insulin-like growth factor-I in 1030 healthy children, adolescents, and adults: relation to age, sex, stage of puberty, testicular size and body mass index. Journal of Clinical Endocrinology and Metabolism 78 744-752.

Atkin SL, Landolt AM, Jeffreys RV, Hipkin L, Radcliffe J, Squire CR \& White MC 1993 Differential effects of insulin-like growth factor I on the hormonal product and proliferation of glycoprotein-secreting human pituitary adenomas. Journal of Clinical Endocrinology and Metabolism 77 1059-1066.

Berelowitz M, Szabo M, Frohman LA, Firestone S \& Chu L 1981 Somatomedin $\mathrm{C}$ mediates growth hormone negative feedback by effects on both the hypothalamus and the pituitary. Science 212 $1279-1281$.

Blaise O, Weil C \& Le Bail PY 1995 Role of IGF-I in the control of GH secretion in rainbow trout (Oncorhynchus mykiss). Growth Regulation 5 142-150.

Blaise O, Le Bail PY \& Weil C 1997 Permissive effect of insulin-like growth factor I (IGF-I) on gonadotropin releasing-hormone action on in vitro growth hormone release in rainbow trout (Oncorhynchus mykiss). Comparative Biochemistry and Physiology 116A 75-81.

Cao QP, Duguay SJ, Plisetskaya EM, Steiner DF \& Chan SJ 1989 Nucleotide sequence and growth hormone-regulated expression of salmon insulin-like growth factor I mRNA. Molecular Endocrinology 3 2005-2010.

Chan SJ \& Steiner DF 1994 Structure and expression of insulin-like growth factor gene in fish. In Fish Physiology, vol 13, pp 456-598. Eds WS Hoar, DJ Randall \& JR Brett. New York: Academic Press.

Cohick WS \& Clemmons DR 1993 The insulin-like growth factors. Annual Review of Physiology 55 131-153.

Colle M \& Broussin B 1993 Growth hormone administered to nongrowth hormone deficient small girls: echographic aspect of the gonads and uterus. Annales de Pédiatrie 40 426-431.

Copeland KC, Kuehl TJ \& Castrance VD 1982 Pubertal endocrinology of the baboon: elevated somatomedin-C: insulin-like growth factor I at puberty. Journal of Clinical Endocrinology and Metabolism 55 1198-1201.

Copeland KC, Eichberg JW, Parker Jr CR \& Bartke A 1985 Puberty in the chimpanzee: somatomedin-C and its relationship to somatic growth and steroid hormone concentrations. Journal of Clinical Endocrinology and Metabolism $601154-1160$.

Duan C \& Hirano T 1990 Stimulation of ${ }^{35}$ S-sulfate by mammalian insulin-like growth factor I and II in cultured cartilages of the Japanese eel, Anguilla japonica. Journal of Experimental Zoology 256 347-350.

Duan C \& Hirano T 1992 Effects of insulin-like growth factor-I and insulin on the in vitro uptake of sulphate by eel branchial cartilage: evidence for the presence of independent hepatic and pancreatic sulphation factors. Journal of Endocrinology 133 211-219.

Duan C, Duguay SJ \& Plisetskaya EM 1993 Insulin-like growth factor-I (IGF-I) mRNA expression in Coho salmon, Oncorhynchus kisutch: tissue distribution and effects of growth hormone/prolactin family proteins. Fish Physiology and Biochemistry 11 371-379.
Dufour S 1994 The neuroendocrinology of eel reproduction: from fundamental research to applied problems. Bulletin Français de la Pêche et de la Pisciculture 335 187-211.

Dufour S, Delerue-Le Belle N \& Fontaine Y-A 1983a Development of a heterologous radioimmunoassay for eel gonadotropin. General and Comparative Endocrinology 49 404-413.

Dufour S, Delerue-Le Belle N \& Fontaine Y-A 1983b Effects of steroid hormones on pituitary immunoreactive gonadotropin in European freshwater eel, Anguilla anguilla L. General and Comparative Endocrinology 52 190-197.

Duguay SJ, Park LK, Samadpour M \& Dickhoff WW 1992 Nucleotide sequence and tissue distribution of three insulin-like growth factors I prohormones in salmon. Molecular Endocrinology 6 1202-1210.

Duguay SJ, Lai-Zhang J, Steiner DF, Funkenstein B \& Chan SJ 1996 Developmental and tissue-regulated expression of IGF-I and IGF-II mRNA in Sparus aurata. Journal of Molecular Endocrinology 16 123-132.

Elies G, Groigno L, Wolff J, Boeuf G \& Boujard D 1996 Characterization of insulin-like growth factor type 1 receptor messenger in two teleost species. Molecular and Cellular Endocrinology 124 131-140.

Frisch R \& McArthur JW 1974 Menstrual cycle: fatness as a determinant of minimum weight for height necessary for their maintenance or onset. Science 185 949-951.

Frisch RE, Hefsted MD \& Yoshinaga K 1977 Carcass components at first estrus of rats on high fat and low fat diets: body water, protein and fat. Proceedings of the National Academy of Sciences of the USA 74 379-383.

Froesch ER, Schmid C, Schwander J \& Zapf J 1985 Actions of insulin-like growth factors. Annual Review of Physiology 47 443-467.

Funkenstein B, Silbergeld A, Cavari B \& Laron Z 1990 Growth hormone increases plasma levels of insulin-like growth factor (IGF-I) in a teleost, the gilthead bream (Sparus auratus). Journal of Endocrinology 120 R19-R21.

Giudice LC 1992 Insulin-like growth factors and ovarian follicular development. Endocrine Reviews 13 641-669.

Gutiérrez J, Parrizas M, Carneiro N, Maestro M \& Planas J 1993 Insulin and IGF-I receptors and tyrosine kinase activity in carp ovaries: changes with reproductive cycle. Fish Physiology and Biochemistry 11 247-254.

Handelsman DJ, Sapliviero JA, Scott CD \& Baxter RC 1987 Hormonal regulation of the peripubertal surge of insulin-like growth factor-I in the rat. Endocrinology 120 491-496.

Hansson HA, Billig H \& Isgaard J 1989 Insulin-like growth factor I in the developing and mature rat testis: immunohistochemical aspects. Biology of Reproduction 40 1321-1328.

Hiney JK, Ojeda SR \& Dees WL 1991 Insulin-like growth factor I: a possible metabolic signal involved in the regulation of female puberty. Neuroendocrinology $\mathbf{5 4} 420-423$.

Hiney JK, Srivastava V, Nyberg CL, Ojeda SR \& Les Dees W 1996 Insulin-like growth factor I of peripheral origin acts centrally to accelerate the initiation of female puberty. Endocrinology 137 3717-3728.

Huang Y-S, Schmitz M, Le Belle N, Chang C-F, Quérat B \& Dufour S 1997 Androgens stimulate gonadotropin-II $\beta$-subunit in eel pituitary cells in vitro. Molecular and Cellular Endocrinology 131 157-166.

Huang Y-S, Rousseau K, Le Belle N, Vidal B, Burzawa-Gérard E, Marchelidon J \& Dufour S 1998 Opposite effects of insulin-like growth factors (IGFs) on gonadotropin (GtH-II) and growth hormone $(\mathrm{GH})$ production by primary culture of European female eel pituitary cells. In Proceedings of Third International Symposium on Research for Aquaculture, August 1997, Barcelona, Spain. Aquaculture (In Press).

Ikeda A, Matsuyama S, Nishihara M, Tojo H \& Takahashi M 1994 Changes in endogenous growth hormones secretion and onset of puberty in transgenic rats expressing human growth hormone gene. Endocrine Journal 41 523-529. 
Jones JI \& Clemmons DR 1995 Insulin-like growth factors and their binding proteins: biological actions. Endocrine Reviews 16 3-34.

Kagawa H, Moriyama S \& Kawauchi H 1995 Immunocytochemical localization of IGF-I in the ovary of the red seabream, Pagrus major. General and Comparative Endocrinology 99 307-315.

Kanematsu T, Irahara M, Miyake T, Shitsukawa K \& Aono T 1991 Effect of insulin-like growth factor I on gonadotropin release from the hypothalamus-pituitary axis in vitro. Acta Endocrinologica 125 227-233.

Kennedy CC \& Mitra J 1963 Body weight and food intake as initiating factors for puberty in the rat. Journal of Physiology 166 408-418.

Lauder GV \& Liem KF 1983 Patterns of diversity and evolution in ray-finned fishes. In Fish Neurobiology, 1st edn, vol 1, pp 2-24. Eds RC Northcutt \& RE David. Ann Arbor: University of Michigan Press.

Le Bail PY 1988 Growth-reproduction interaction in salmonids. In Reproduction in Fish - Basic and Applied Aspects in Endocrinology and Genetics, pp 91-108. Eds Y Zohar \& B Breton. Paris: INRA.

Le Gac F, Blaise O, Fostier A, Le Bail PY, Loir M, Mourot B \& Weil C 1993 Growth hormone $(\mathrm{GH})$ and reproduction: a review. Fish Physiology and Biochemistry 11 219-232.

Luna AM, Wilson DM, Wibbloman CJ, Brown R, Nagashima RJ, Hintz RL \& Rosenfeld RG 1983 Somatomedins in adolescence: a cross-sectional study of the effect of puberty on plasma insulin-like growth factor I and II levels. Journal of Clinical Endocrinology and Metabolism $\mathbf{5 7}$ 268-271.

McNabb FMA 1994 Physiological actions of thyroid hormones. In Thyroid Hormones, pp 165-196. New Jersey: Prentice-Hall.

Marchelidon J, Schmitz M, Houdebine LM, Vidal B, Le Belle N \& Dufour S 1996 Development of a radioimmunoassay for European eel growth hormone and application to the study of silvering and experimental fasting. General and Comparative Endocrinology 102 360-369.

Monniaux D \& Pisselet C 1992 Control of proliferation and differentiation of ovine granulosa cells by insulin-like growth factor I and follicle-stimulating hormone in vitro. Biology of Reproduction $\mathbf{4 6}$ 109-119.

Montero M, Le Belle N, Vidal B \& Dufour S 1996 Primary culture of dispersed pituitary cells from estradiol-pretreated female silver eel (Anguilla anguilla): immunocytochemical characterization of gonadotropic cells and stimulation of gonadotropin release. General and Comparative Endocrinology 104 103-115.

Ojeda SR \& Urbanski HF 1988 Puberty in the rat. In The Physiology of Reproduction, vol 2, pp 1699-1737. Eds E Knobil, JD Neill, LL Ewing, GS Greenwald, CL Markert \& DW Pfaff. New York: Raven Press.

Pérez-Sànchez J, Weil C \& Le Bail PY 1992 Effects of human insulin-like growth factor-I on release of growth hormone by rainbow trout (Oncorhynchus mykiss) pituitary cells. Journal of Experimental Zoology 262 287-290.

Plant TM 1988 Puberty in primates. In The Physiology of Reproduction, vol 2, pp 1763-1788. Eds E Knobil, JD Neill, LL Ewing, GS Greenwald, CL Markert \& DW Pfaff. New York: Raven Press.

Plisetskaya EM, Duguay SJ \& Duan C 1994 Insulin and insulin-like growth factor I in salmonids: comparison of structure, function, and expression. In Perspectives in Comparative Endocrinology, pp 226-233. Eds KG Davey, RE Peter \& SS Tobe. Ottawa: National Research Council of Canada.

Quérat B 1994 Molecular evolution of the glycoprotein hormones in vertebrates. In Perspectives in Comparative Endocrinology, pp 27-35.
Eds KG Davey, RE Peter \& SS Tobe. Ottawa: National Research Council of Canada.

Roberts BL, Meredith GE \& Maslam S 1989 Immunocytochemical analysis of the dopamine system in the brain and spinal cord of the European eel, Anguilla anguilla. Acta Embryologica 180 401-412.

Roberts CA, McCutcheon SN \& Blair HT 1990 Developmental patterns of plasma insulin-like growth factor-I concentrations in sheep. Domestic Animal Endocrinology 4 457-463.

Rousseau K, Huang YS, Le Belle N, Vidal B, Marchelidon J, Epelbaum J \& Dufour S 1998 Long-term inhibitory effects of somatostatin and insulin-like growth factor I on growth hormone release by serum-free primary culture of pituitary cells from European eel (Anguilla anguilla). Neuroendocrinology 67 301-309.

Schwartz J \& Cherny R 1992 Intercellular communication within the anterior pituitary influencing the secretion of hypophysial hormones. Endocrine Reviews 13 453-475.

Shamblott MJ, Cheng CM, Bolt D \& Chen TT 1995 Appearance of insulin-like growth factor mRNA in the liver and pyloric ceca of a teleost in response to exogenous growth hormone. Proceedings of the National Academy of Sciences of the USA 92 6943-6946.

Soldani R, Cagnacci A \& Yen SS 1994 Insulin, insulin-like growth factor I (IGF-I) and IGF-II enhance basal and gonadotropinreleasing hormone-stimulated luteinizing hormone release from rat anterior pituitary cells in vitro. European Journal of Endocrinology 131 641-645.

Soldani R, Cagnacci A, Paoletti AM, Yen SS \& Melis GB 1995 Modulation of anterior pituitary luteinizing hormone response to gonadotropin-releasing hormone by insulin-like growth factor I in vitro. Fertility and Sterility 64 634-637.

Stanhope R, Hindmarsh P, Pringle PJ, Holownia P, Honour J \& Brook CG 1987 Oxandrolone induces a sustained rise in physiological growth hormone secretion in boys with constitutional delay of growth and puberty. Pediatrician 14 183-188.

Swanson P \& Dittman A 1997 Pituitary gonadotropins and their receptors in fish. In Advances in Comparative Endocrinology, vol 1, pp 841-846. Eds S Kawashima \& S Kikuyama. Bologna, Italy: Monduzzi Editore.

Takahashi S, Oomizu S, Honda J \& Takeuchi S 1997 Insulin-like growth factor-I system in the mouse pituitary. In Advances in Comparative Endocrinology, vol 2, pp 1123-1126. Eds S Kawashima \& S Kikuyama. Bologna, Italy: Monduzzi Editore.

Thissen JP, Ketelslegers JM \& Underwood LE 1994 Nutritional regulation of the insulin-like growth factors. Endocrine Reviews $\mathbf{1 5}$ 80-101.

Tilemans D, Andrier M, Straetemans L \& Denef C 1991 Luteinizing hormone-releasing hormone and neuropeptide $\mathrm{Y}$ influence deoxyribonucleic acid replication in three anterior pituitary cell types. Evidence for mediation by growth factors released from gonadotrophs. Endocrinology 130 882-894.

Upton Z, Francis GL, Chan SJ, Steiner DF, Wallace JC \& Ballard EJ 1997 Evolution of insulin-like growth factor (IGF) function: production and characterization of recombinant hagfish IGF. General and Comparative Endocrinology 105 79-90.

Yamashita S \& Melmed S 1986 Insulin-like growth factor I action on rat anterior pituitary cells: suppression of growth hormone secretion and messenger ribonucleic acid levels. Endocrinology 118 176-182.

\section{Received 9 February 1998}

Accepted 18 May 1998 